\title{
Conflicts of Interest, Culture Jamming and Subversive (S)ignifications: The High Fashion Logo as Locational Hip Hop Articulation
}

Rebecca Halliday

York University

In the fall of 2012, an unheard of fashion label called "Conflict of Interest NYC" (C.O.I.) released three black and white, unisex t-shirts for sale online. Each t-shirt took the brand name and/or logo of a storied fashion house - Balenciaga, Bottega Veneta and Givenchy - and imposed a set of urban and sexualized representations and hip hop references to enact a high-end-low-end subversion of the brand's connotations. The t-shirts came to public attention after Internet "street style" photographer Tommy Ton captured New York fashion editor Shiona Turini wearing a BALLINCIAGA t-shirt on the street at London Fashion Week and posted it on Condé Nast Media's fashion bible Style.com. This article contextualizes the $\mathrm{t}$-shirts within historical interactions between fashion and hip hop culture and reads the BALLINCIAGA t-shirt for its intertextual connections to hip hop and black oral tradition. ${ }^{1}$ In this sense, my analysis constitutes a "translation" of and between sets of cultural "codes" (Hall 21): in this instance, a translation of fashion brand names and subcultural references. Conflict of Interest's t-shirts present a sophisticated incidence of culture jamming that parodies high fashion brands through hip hop references; it thus criticizes high fashion's historical Eurocentric elitism and articulates urban conditions. While the t-shirts were not created as an explicit political protest, they are indeed subversive, and their creation and proliferation from within fashion illuminates the politics of fashion's cultural appropriations and socioeconomic identities. I later examine Ton's photograph of Turini as a moment of resistance, but also of high fashion's re-appropriation of the tshirts' racial references. Nonetheless, the t-shirts' circulation as commodities enacts a measure of political potential and opens a space for reflection on the tensions between fashion and urban, subcultural communities.

\section{Culture Jamming and Parody as Political Practice}

C.O.I.'s brand performance is elaborate: members describe themselves as "secret agents" within a government bureau that conducts "raids" for and then resells counterfeit designer goods ("About Us"). In positioning its members as both fashion and legal authorities, the team comments on the continued problem of counterfeit products and insiders' concerns around brand authenticity and cultural status. ${ }^{2}$ The t-shirts are labeled, cunningly, as "legitimate counterfeit products" and mailed to customers in Ziploc bags marked with an official seal (which doubles as the brand logo), the words "EVIDENCE" and "SEIZURE" and the style name and size written in black marker. In brief, C.O.I. treats its wares as counterfeits under the pretense of respect for the status of the brands it has parodied. Media reports indicate that the members work in fashion but do not wish to reveal their identities, as a condition of

\footnotetext{
${ }^{1}$ I presented a draft of this article at the "Placing Imaginaries of Fashion and Style" seminar at the 2013 meeting of the American Comparative Literature Association at the University of Toronto. Thanks to the organizers and participants of that seminar for their helpful comments.

${ }^{2}$ On fashion counterfeits in the present, see Dana Thomas. On the role of the label in historical tensions between haute couture and counterfeits, see Nancy Troy, especially chapter 4.
} 
their supposed professional roles and as a public relations tactic: to maintain a sense of subversion around their initiative, as well as to create "mystery and excitement" around the brand itself (Chernikoff). In a 2013 Fashionista interview, a C.O.I. member notes that their anonymity permits them to "observe" the fashion scene undetected: "to know what's out there and to know what to pick during our warehouse raids" (Chernikoff). The interviewer jokes that for the members to reveal their names would be a "conflict of interest," since their anonymity is crucial to their 'covert' operations (Chernikoff). It is implied, however, that for industry personnel to produce a line that parodies trademarked brand names and logos constitutes a professional conflict of interest. Other publications posit that members are concerned about legal action from the targeted fashion houses (Elliott; Small). ${ }^{3}$

The C.O.I. t-shirts operate as a form of parody: C.O.I.'s members use the term to describe the team's method, as do related media discourses, but their description can be substantiated through a review of definitions of parody from literary and cultural theorists. C.O.I. as an artistic collective declares that it admires the high fashion brands and that the subversions are done in fun: "We are definitely fans of the labels we parody, and if we don't love the original house, designer, or logo, we don't touch it" (Adams; see also "Opinion"; Small). C.O.I. elaborates that the appropriations arose out of "hilarious conversations [and] wordplay" (Adams). Nonetheless, the media has failed to pick up on the political element that often underlies parody, or the t-shirts' more layered implications, contained in the references to hip hop and black oral culture. There is far more semiotic and intertextual work happening in these t-shirts than the media has thus far described. The next section contextualizes C.O.I.'s subversive t-shirts within practices of semiotic appropriation: from culture jamming, to Linda Hutcheon's definition of parody, to Henry Louis Gates's identification of parody's more political turn in the process of Signifyin(g).

Culture jamming, the alteration or recombination of consumer and media representations, has become a popular activist practice in the late capitalist era and is often directed at advertisements and brands; culture jamming should not be conflated with parody but uses it as a method. It can be traced back to Dadaist and other similar critical art practices, and later to Debord and the Situationists: specifically the method of detournement that Debord called for to resist the bombardment of commodities that formed the spectacle (Klein 283-84; Lievrouw 34). The student revolts in France in 1968 instituted their own street art practices in the form of graffiti and of alternative maps of Paris as “détourned" (Lievrouw 38). The critic Mark Dery characterized culture jamming for the mainstream public in the 1990s and credits the band Negativland with the first use of the term in 1984. In the 1980s, culture jammers altered billboards and plastered streets with subversive political posters; since the 1990s, jammers have targeted print and online advertisements and founded alternative publications such as Adbusters (Lievrouw 73-74). Online media has facilitated the formation of an international network of practitioners and audiences (Klein 285). Media scholar Leah Lievrouw emphasizes that culture jamming operates from within popular culture, rendering its ironic criticism at the level of the

\footnotetext{
${ }^{3}$ Fashion houses have had different reactions to parodic t-shirts. Saint Laurent pulled its line from the retailer Colette after Colette sold a t-shirt that read "Ain't Laurent Without Yves," produced by New York t-shirt line Reason, at its Paris boutique (Elliot). However, C.O.I. claims that Givenchy head designer Riccardo Tisci owns one of their GIRAUNCHY tshirts (Epstein).
}

This work is licensed under a Creative Commons Attribution 3.0 License 
sign: "media artists and activists appropriate and 'repurpose' elements from popular culture to make new works with a subversive point" (22). Rather, the practice is conducted from inside of the spectacle, as a mode of resistance rather than an impossible rupture (72). Culture jamming interrupts familiar associations to spark critical reflection on the dominant culture's "inequities, hypocrisies, and absurdities" from within the noise (80). On a practical level, initiatives are "collaborative" and smallscale and aim to create a powerful social effect in a brief period (Lievrouw 92-97). C.O.I.'s initial t-shirt release fits this criteria, though the label's more recent success has seen it transcend the parameters of more political works; still, its use of subversion within the fashion scene demonstrates an acute comprehension of subcultural references. ${ }^{4}$

Linda Hutcheon's definition of parody as "imitation with critical distance" predicated on a bidirectional ironic "inversion" is useful here, as it accounts for possibilities for both serious and comedic intent in the combination of intertextual references (36-37). Hutcheon formulates parody as holding potential for harmless fun but also for criticism, and indeed culture jamming as practice uses this method for both ends. Parody here encompasses both the sort of respectful approach that C.O.I. claims to take in relation to fashion houses and the more political articulations that I will describe, as its critical function can be "playful as well as belittling ... critically constructive as well as destructive" (32). Parody's "enunciative" function resides in the "superimposition" of one set of textual references onto another to emphasize an element of "contrast" that the reader appreciates as such (34). Its effect is achieved through the interaction between author and reader and therefore requires in both parties the comprehension of each set of references: "parody demands that the semiotic competence and intentionality of an inferred decoder be posited ... both the encoding and the sharing of codes between producer and receiver are central..." (37). Likewise, Lievrouw states that culture jamming requires the "subcultural literacies" of both creator and audience to understand the codes (62). To call the C.O.I. tshirts parodies indemnifies the creators from accusations of plagiarism, at least in a scholastic sense. Hutcheon differentiates between parody and plagiarism based on the former's emphasis of difference from the source text and the reader's recognition of that difference (38-39). C.O.I. asserts that no astute fashion aficionado would misrecognize the brand names: "There's no person who sees these shirts and thinks they are actually from the brands being parodied. The only way you know these brands in the first place is if you're into fashion, and nobody in fashion would think these are made by the houses they parody" (Elliott). Though parody is distinct too from more political forms of satire, its humour can be honed to render social critique (Hutcheon 46). 1960s pop art, in particular that of Warhol, offered a "parodic satire" of consumer culture (47). It is cited as a predecessor to present-day forms of culture jamming (Lievrouw 30).

The specific type of semiotic appropriation that C.O.I. uses for its line of t-shirts is that of Signifyin(g), a post-colonial formation with more overt political intent than Hutcheon's notion of parody. Henry Louis Gates theorizes that Signifyin(g) constitutes the "repetition and revision or

\footnotetext{
${ }^{4}$ Though its initial capsule collection fit with Lievrouw's characterization of culture jamming initiatives as small-scale and brief, C.O.I. has since released seven more t-shirts, in addition to stickers and sweatshirts. It held a presentation at Mercedes-Benz Fashion Week in September 2013 with a similar streetwear line, LPD. The line can also be found at select stores in the United States and the retailer Brown's in London (Chernikoff).
}

This work is licensed under a Creative Commons Attribution 3.0 License 
repetition with a signal difference" of a signifier from white, Eurocentric discourse - replicated in an altered form that connotes blackness (xxii-xxiv). Explicating the method's political aspect, Gates classifies parody as the operation of "motivated Signifyin(g)": the creation of alternate representations from political aims, as opposed to the more superficial practices of pastiche (xvi). Different from culture jamming's insertion of a counter-representation, Signifyin(g) permits for a doubled representation that holds up both the familiar and the Other to create a moment of deferral: the result is a "disturbance in silence" rather than an interruption in noise (53). Black oral traditions further illuminate (or function as) intertextual relations within and between forms (Gates xxi). For Gates, Signifyin(g) can be found in several hip hop forms, including rap (88). Here, as hip hop scholar Tricia Rose explains, rappers "layer meaning by using the same word to signify a variety of actions and objects" (Black Noise 39). The C.O.I. t-shirts can thus be seen as an articulation of Gates's notion of "black difference" against high fashion's often whitewashed, elitist landscape (xxii). Therefore, in the context of the black oral vernacular tradition, C.O.I. members' use of the term parody, and its method, implies humourous and political subversion.

\section{Hip Hop Culture and Its Relations to Fashion}

Although other t-shirt lines with ironic commentaries on fashion house names have been released in this decade, C.O.I.'s t-shirts are notable for their intelligent and intertextual use of hip hop signifiers, street slang and black oral vernacular. Interestingly, one C.O.I. member uses the word "remix" to describe the collective's method, further connecting it to hip hop forms (Remsen). This article relies on a broad definition of hip hop that is connected to postmodern and postcolonial articulations and rooted in African-diasporic oral traditions (Rose, "Style" 72). Hip hop started as a subculture but has gained broad acceptance in mainstream, commercial culture. Hip hop has manifested into a multitude of articulations, aesthetics, signifiers, styles, genres and embodied repertoires in international arenas (Briggs and Cobley; Dimitriadis). Its three "central forms - graffiti, breakdancing and rap music," contain additional sub-forms (Rose, "Style" 73). Scholars locate hip hop's emergence in the impoverished and ghettoized black and Hispanic communities that resulted from New York's gentrification in the mid-1970s: notably in the South Bronx (Romero 7; Rose, "Style" 76-77). Hip hop, and its fashions, offered its publics the chance to articulate an alternate set of multifarious ethnic identities in the post-Civil Rights and post-industrial era, and to resist the economic conditions that political and social institutions had assigned to them (Romero 9; Rose, "Style" 78). Music scholar Elena Romero notes that hip hop fashion earned its initial name, "urbanwear," from its birth in these same communities (xiii). "Urban" thus references both a subcultural form and its street environments.

The subversive effect of Conflict of Interest NYC's appropriation of fashion house logos resides in dichotomies between aristocratic, European-based high fashion, for the dominant (white) classes, and hip hop fashion as an expression of life in disenfranchised black and Latino areas. High fashion remained inaccessible to these communities into the 1980s, due to fashion houses' hesitation to associate their brands with black celebrities, and to the clothes' prohibitive price points. Tensions between urban consumers and fashion houses were exacerbated as blacks and Latinos fashioned counterfeits of premium fashions to assert their right to a high economic status (Romero 10, 83-87).

This work is licensed under a Creative Commons Attribution 3.0 License 
Hip hop's proliferation into mainstream culture across the mediums of fashion, music, film and television, along with the resultant rise in cultural and economic status of hip hop artists and black celebrities, led fashion houses to take notice of both a potential consumer base and an expanding cultural movement (Romero 161). Romero's account of the hip hop fashion business illustrates that its entrance into a wider marketplace lent members of black communities cultural credence. Several fashion houses appropriated hip hop signifiers: "In 1984, Norma Kamali showed her collection in a hip hop influenced video. Chanel followed in 1987 with a hip hop-infused collection that included gold door-knocker earrings, oversized baseball jackets, and Kangol cap-like replicas" (161). Romero credits rapper and actor Sean Combs with instantiating hip hop fashion within the realm of high fashion through his successful Sean John line (146-47). Media scholar Roopali Mukherjee sees hip hop's commercial form as an incidence of dominant cultural co-optation (604). Rose, however, contends that hip hop has always operated within consumer culture, and that its "moment(s) of 'incorporation' are a shift in the already existing relationship hip hop has always had to the commodity system" ("Style" 83). Still, hip hop's commercial ties are problematic. Hip hop's "ghetto fabulous" or "bling" aesthetic reappropriates luxury commodities and counterfeits as a "resistant" articulation of blackness and urban life (Mukherjee 612); it perpetuates "hedonistic consumerist excesses" that imbricate black youth in capitalist structures (606). Further, it is notable that fashion's 'acceptance' of hip hop has neither erased socioeconomic distinctions nor eliminated political and cultural tensions - tensions which are often articulated at the semiotic level of the brand in particular.

The logo offers a productive medium through which to manipulate a brand's connotations, as it is the signifier for the brand and its cultural status and historical associations (Okonkwo 109-10). In consumer culture, the logo is the semiotic "face" of and media "interface" with the brand: it most often includes, but is not limited to, the brand name, in the form of textual and graphic representation (Lury 62). ${ }^{5}$ The high fashion logos manipulated here are subtle and 'refined' but are nonetheless potent signifiers for the brands' elitist and Eurocentric associations, in addition to seals of authenticity (Troy 26-28). Premium brand logos (or their approximations) also function as signifiers in counterfeits. In hip hop culture, logos - as identifiers for hip hop fashion brands, designer brands and athletic brands - serve numerous functions. Members flaunted premium brand logos if they had the capital to purchase the products or used "fake Gucci and other designer emblems cut up and patch-stitched to jackets, pants, hats, wallets and sneakers" as an offense to those that could afford the genuine article (Rose, "Style" 80). This juxtaposition constituted a practice of bricolage that "re-located" and thus altered their cultural referents (Clarke, qtd. in Hebdige

103). Romero describes the calculated design of hip hop brand logos, from their semiotic prominence in popular brands such as FUBU (For Us By US) (115), to Sean John's small, scripted logo, similar to those of dominant fashion houses, to "provide a clean, sophisticated urban brand" (146). The logo as construct offered members of urban communities the chance to articulate distinct identities from within hip hop and remains a semiotic anchor for relations between high and mainstream hip hop fashion, as the C.O.I. t-shirts smartly illustrate.

${ }^{5} \mathrm{I}$ refer to the names that C.O.I. parodies as fashion houses to reference their histories as such but note that their logos also reflect their current status as corporate brands. Lury sees the brand as a material formation that mediates consumers' brand and social relations (1-2).

This work is licensed under a Creative Commons Attribution 3.0 License 
TranscUlturAl, vol. 6.1 (2014), 70-83.

http://ejournals.library.ualberta.ca/index.php/TC

\section{BALLINCIAGA and the Hip Hop Subversion of the Balenciaga Brand}

Balenciaga is one of Europe's most respected but also counterfeited luxury brands. The Basque designer Cristobal Balenciaga founded his fashion house in 1918 and went on to dress Spanish and Belgian queens, in addition to the twentieth century's most celebrated fashion icons. Balenciaga trained in Madrid but relocated to Paris after the outbreak of the Spanish Civil War and established himself as one of Paris's top couturiers. The couture house closed its doors in 1968, and the designer died in 1972. The house reopened as a ready-to-wear line in 1987. The French-born Nicolas Ghesquière became its creative director in 1997 and re-established Balenciaga as a consecrated brand ("Balenciaga"). In 2001, the Gucci Group, under the corporation Pinault-Printemps-Redoute (now called Kerig), acquired the fashion house. ${ }^{6}$ The Balenciaga logo (there are different incarnations) lists the house's name under a mirrored letter "B" connected at the stem by three diagonal lines. "Paris" appears under the house name. The logo used for the C.O.I. t-shirt is printed onto the box that contains the fragrance "Balenciaga Paris": it includes the house name and the address of its Paris atelier ("Balenciaga Paris") (see fig. 1).

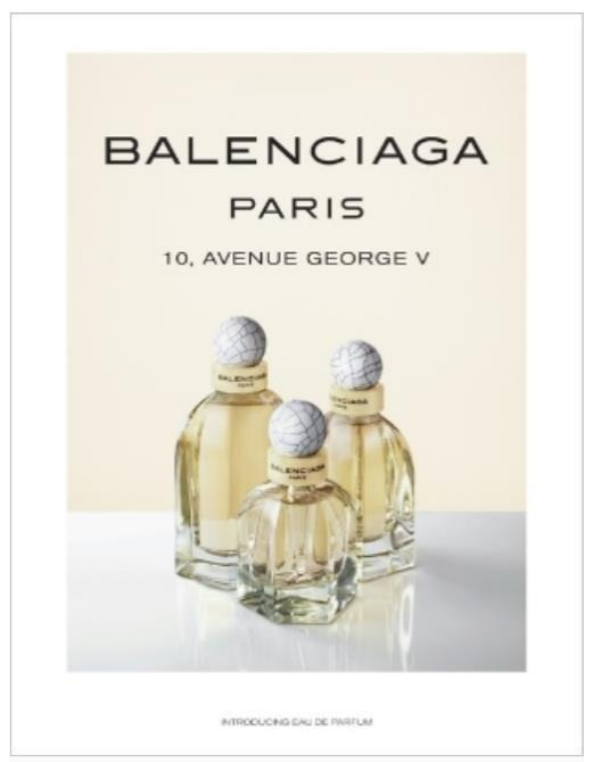

Fig. 1. The logo featured on the box for the fragrance Balenciaga Paris.

The BALLINCIAGA t-shirt offers C.O.I.'s most subversive and layered manipulation of the fashion house's logo, incorporating hip hop and broader urban textual references and historical locations (see fig. 2). ${ }^{7}$

${ }^{6}$ In 2012, after the release of the BALLINCIAGA t-shirt, PPR named American designer Alexander Wang, known for a more casual 'streetwear' aesthetic, as his successor.

${ }^{7}$ Although I am familiar with rap music, I am referencing the open-source Internet sites Urban Dictionary and Genius to aid in the comprehension of subcultural codes and find more possibilities for interpretation. I need to address the merits of this approach. Here, I feel that "crowdsourcing" information from urban communities or hip hop aficionados taps into the collective "general store of intellectual capital" (Howe 16), or contributors' "subcultural acuity" (Lievrouw 96). Further, I am not just rendering a singular, authoritative interpretation. New York Times columnist Virginia Heffernan heralds $U D$, active since 1999, as a "stunningly useful document" for access to youth culture. I note that definitions are 


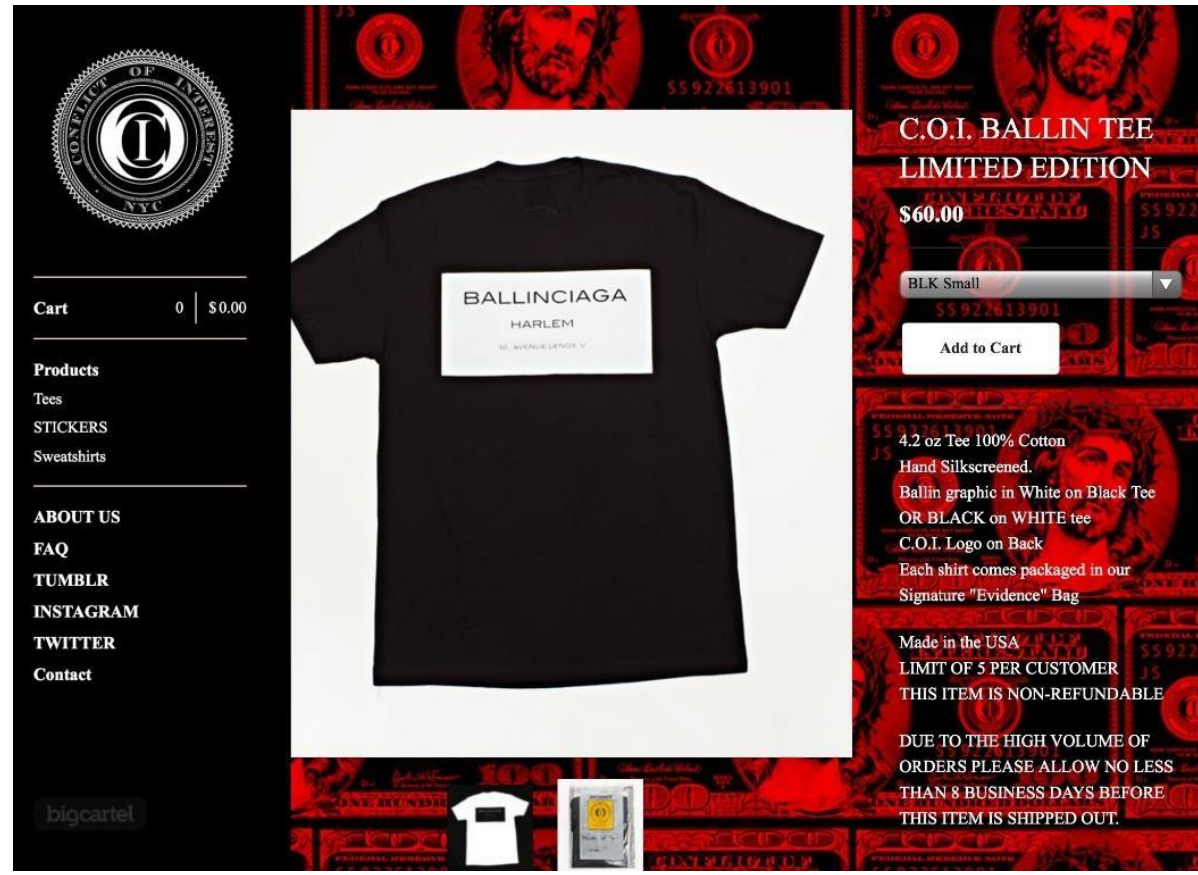

Fig. 2. Conflict of Interest NYC's BALLINCIAGA t-shirt.

The first semiotic inversion is a textual effect, rooted in the insertion of the multifarious slang term "ballin" into the house name: a manipulation of letters that adds a set of humorous but also controversial meanings. The process of Signifiyin $(\mathrm{g})$ that occurs here is that of agnominiato, "the repetition of the word with a change denoted by a difference in sound or in a letter that forms an aural [and] a visual pun": a subtle phonetic difference that yields a seismic shift in the "sound-image' or in the concept" (Gates 45). "Ballin" has its roots in ebonics (Urban Dictionary). Its truncated spelling is derived from the black oral vernacular tradition, in the same manner as the term Signifyin(g) itself (Gates 45). The absence of the " $g$ " indicates the term's spoken pronunciation and, in the context of the t-shirt, both connects the slang term to the rest of the fashion house's name, so that its pronunciation remains almost intact, but, at the same time, "stands as the trace of black difference" (45).

To trace the term "ballin" through popular rap music helps to articulate its multiple meanings. An initial definition of "ballin" is to have sexual intercourse. ${ }^{8}$ In "Niggas in Paris," a successful 2011 duet by Jay- $Z$ and Kanye West, the term describes the act in a crude manner:

She said, "Ye [Kanye], can we get married at the mall?" I

said, "Look, you need to crawl 'fore you ball.

Come and meet me in the bathroom stall

constantly updated or re-numbered based on user monitoring. Founded in 2009 to annotate rap lyrics, Rap Genius has become a multi-million-dollar tech brand and as of July 2014 renamed itself Genius (Constine); like Wikipedia, its annotations include references to media sources.

${ }^{8}$ I note that this definition was edited on UD since earlier drafts of this article and is now listed under "balling" rather than "ballin". 
TranscUlturAl, vol. 6.1 (2014), 70-83.

http://ejournals.library.ualberta.ca/index.php/TC

And show me why you deserve to have it all." ("Paris")

"Crawl before you ball" is a rhyming play on the phrase "crawl before you walk" ("Paris"). Here, West demands that the woman perform sexual acts before he will give her material possessions ("Paris"). The doubled reference to male genitalia implies the sexual dominance of the male. "Ballin"' here inserts crass connotations that contradict the fashion house's tasteful associations. The term's second definition is "to play basketball" (UD); to "ball hard" is to commit a "rough foul" ("Paris"). Jay-Z's first line, "So I ball so hard mothafuckas wanna fine me," references a 2011 incident in which NBA officials fined the rapper, a part owner of the New Jersey Nets, 50,000 dollars for visiting the Kentucky Wildcats' locker room ("Paris"; see also Stein). "Ball so hard" becomes a refrain that then assumes a doubled, sexual connotation.

Additional definitions reference practices of conspicuous consumption, both in black communities and in high fashion. To be "ballin" is first to live a life of "extreme wealth" $(U D)$. A variation, "[t]o live a rich, upperclass life after growing up [in] a poor - ghetto - low class life" (UD) recalls black urban youth's ideal of a rise from economic disenfranchisement (Mukherjee 600). The fact that the term appears on a track about hip hop stars living in conspicuous luxury in Paris, with hundreds of millions of dollars to do so, suggests the artists' "ghetto fabulous" act of defiance to Paris's Eurocentric elitism. A related definition describes consumption despite an absence of funds: "young people from not so wealthy families think its [sic] cool to blow off thousands of dollars on jewlry [sic] and clothes instead of trying to move out of the ghetto..." (UD). The t-shirt's linguistic slippage through Signifyin(g) here criticizes high fashion's astronomical prices and its classism: the social conditions that led to the consecration of the Balenciaga name and thus the t-shirt's creation. Subsequent definitions, including "selling large quantities of drugs" or "to perform illegal or shady actions to make and/or keep money," reinforce the real problems that result from crime $(U D)$. These definitions also invoke the drug trade: "ball" as a noun refers to a $1 / 8$ ounce of cocaine $(U D)$. In his song "Ballin" (ft. Lil Wayne), the rapper Jeezy, a former Atlanta drug dealer, boasts of his possessions. The refrain, "You think you ballin' cause you got a block?" mocks small-time dealers that control sections of the streets ("Ballin"). This track illustrates the term's more controversial connotations for those that can read such intertextual references. ${ }^{10}$ Representations of urban crime run in a polar contrast to the high-class and aesthetic ideals the Balenciaga name invokes and render a parodic but pointed critique of late capitalism's promise of freedom through the purchase of luxury commodities.

The BALLINCIAGA t-shirt alters the place name and address on the Balenciaga logo to reflect an identifiable urban location and its histories. First, "PARIS" becomes "HARLEM". The geographic signifier that offers Balenciaga its historical cache and associations with European streets is now connected to Harlem and the political conditions that created hip hop as a subculture. As one of the

\footnotetext{
${ }^{9}$ Jay-Z is featured on C.O.I.'s Tumblr site wearing a later t-shirt marked ILL SLANDER (a street slang inversion of the fashion house Jil Sander) (coi-nyc.tumblr.com).

${ }^{10}$ For discussion of a far more controversial t-shirt that references the music of the rapper Young Jeezy (and its media fallout) and a call for the need to examine these representations as reflections of the material conditions of urban communities, see Penney.
}

This work is licensed under a Creative Commons Attribution 3.0 License 
"ghettoized urban areas" from which "largely poor, black and Latino youth" sought to articulate and resist their lot, Harlem, like the South Bronx, played an important role in hip hop's development (Dimitriadis 2). Harlem became home to prominent clubs, such as Harlem World, famous for hosting rap battles $(23,36)$. Harlem is also considered the birthplace of hip hop fashion, first due to the Harlem Renaissance (Romero 47), and, decades later, a proliferation of independent retailers and tailors (x, 1416). Harlem is the home of the counterfeit impresario Dapper Dan, who tailored intricate and expensive replica suits that used logos and printed fabrics associated with fashion houses such as "Louis Vuitton, Gucci, Chanel, and MCM" in the 1980s, when European fashion houses refused to cater to black celebrities (83). Dapper Dan's clientele list included “drug dealers, hustlers, rap stars, entertainers and athletes" (83). Furthermore, the BALLINCIAGA t-shirt replaces the address "10, AVENUE GEORGE V" with "10, AVENUE LENOX V". The address reflects the 'proper' French order for a street address and thus imbues Harlem with an ironic Eurocentric cache. In the 1980s, Dapper Dan's 'atelier' was located at the corner of $125^{\text {th }}$ Street and Lenox Avenue (Romero 77). C.O.I.'s alteration of the atelier address creates a neat moment of (S)ignification that doubles the idea of the storefront but inverts the status of the high-end products, especially as Dapper Dan created beautiful reproductions (83). It hints at the address of a man famous for appropriating and subverting the integrity that Balenciaga and other couturiers stood for. Thus, the t-shirt's reference to "Avenue Lenox" calls the foundations of brand status into question and exposes the more Eurocentric biases that led high fashion to exclude black consumers. Lenox Avenue was renamed "Malcolm X Boulevard" in the 1980s ("Malcolm X Boulevard"). Thus, the name references Harlem at the start of the hip hop era but also invokes a potent historical figure in the Civil Rights movement.

\section{BALLINCIAGA at London Fashion Week and High Fashion's Re-Appropriation}

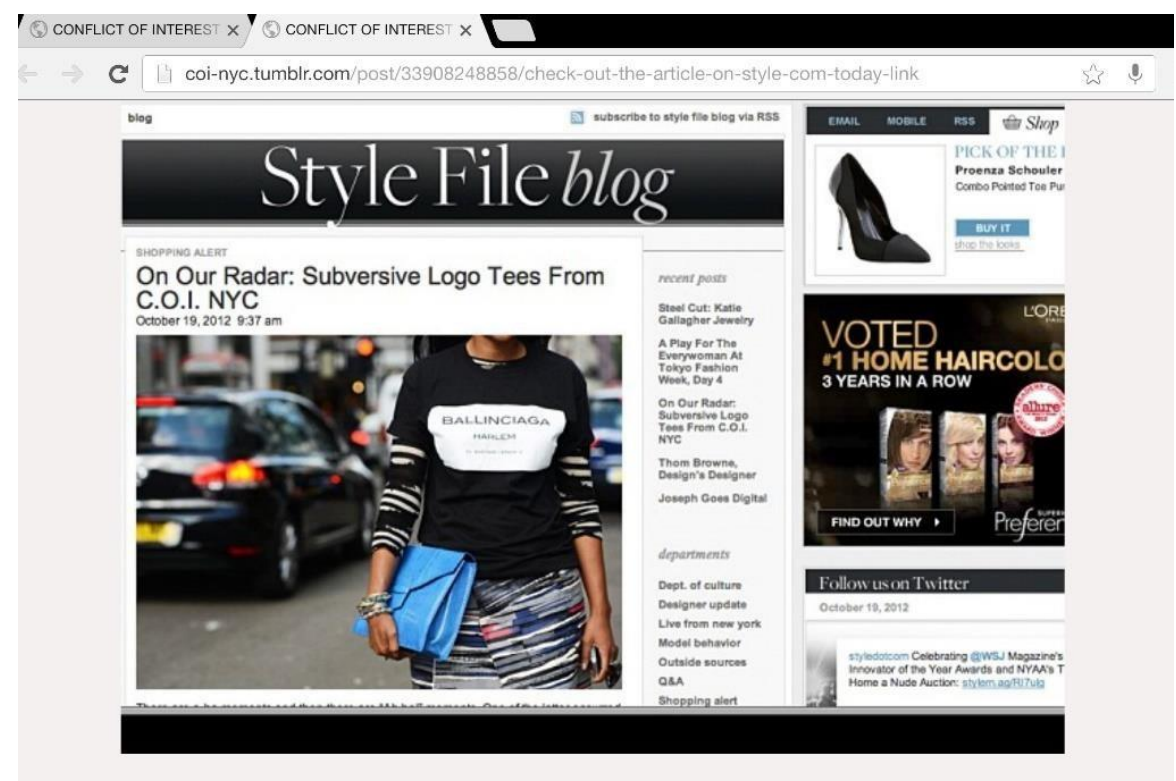

Fig. 3. Tommy Ton's photograph of Shiona Turini at London Fashion Week in October 2012, as posted on Style.com. 
Tommy Ton's photograph of Shiona Turini, wearing the BALLINCIAGA t-shirt at London Fashion Week, indicates a simultaneous moment of cultural articulation and of fashion's reappropriation of the t-shirt (see fig. 3). The photograph's placement on Style.com and its later "viral" circulation incited coverage on C.O.I. and caused an "immediate spike in sales" (Adams). The tshirt's appearance at London Fashion Week presents a distinct clash of "semiotic landscapes," the accumulation of man-made textual, graphic and architectural signs within geographic spaces (Jaworski and Thurlow 2). During Fashion Week, the London street becomes overwritten with high fashion's material codes: constructed barriers and fashion insiders in their often high-end clothes constitute a "human intervention" on already loaded locations (2). Here, the name BALLINCIAGA on Turini's tshirt contrasts with the unaltered brand names on the bodies of Fashion Week's other attendees (in the same album), and on signage in that same environment. At the level of urban semiotics, the t-shirt's reference to Harlem creates a discordant contrast of London architecture and its colonial associations and Harlem in the 1980s, with its celebration of blackness. The photograph's online circulation and the media's focus on the t-shirts as an (apolitical) fashion trend "incorporates" the t-shirts in a form of "labelling" (Hebdige 94): an implication that their subcultural articulations were humourous but need not be elaborated.

In later seasons, the t-shirts' act of subversion has started a discussion of the politics of appropriation. The New York Observer, with a different interpretation, took the brand to task for creating 60 dollar 'counterfeits' and wondered "whether C.O.I. is ... just marking up Canal Street knock-offs for SoHo clientele" (Epstein). From C.O.I.'s perspective, fashion houses' possible negative reactions to the t-shirts are hypocritical: "If they want to make a shirt that references a street culture item references it exactly but puts a spin on it - that's okay. But when it goes the other way they get riled up about it" (Elliott). The t-shirts' references illuminate fashion houses' own liberal appropriation of hip hop signifiers and issue a reminder that hip hop fashion became legitimated in white culture in part through fashion's use of its street-located cultural references. DAZED Digital commends C.O.I. for making consumers "question why we listen to designers, and what drives us to buy into (sometimes without affording to) their branding." C.O.I.'s demonstration of how "words can translate into power on clothing" incites "a new level of awareness for street style" ("Opinion"). However, hip hop culture has understood for decades the political effects of fashion's semiotics, as have numerous other subcultures.

\section{Conclusion}

The Conflict of Interest NYC operation adheres to the practice of culture jamming as an insider criticism of high fashion and consumer culture: the initiative renders parodic statements through hip hop and urban articulations that are humourous and sophisticated but nonetheless illuminate concerns of cultural disenfranchisement and appropriation in fashion and in urban communities. The collections offer a useful incidence to discuss the potentialities of rendering political statements within fashion and the need to read fashion as a set of artifacts, in particular for moments of resistance. In their circulation as commodities, the C.O.I. t-shirts hold a potential for political articulation, even as their creators have positioned themselves further within the field of fashion. C.O.I. posts photographs of

This work is licensed under a Creative Commons Attribution 3.0 License 
customers in their t-shirts on its Tumblr feed. The site presents a plethora of races, bodies and contexts, but it is notable that the t-shirts are often worn with other hip hop signifiers: there is a clear sense that customers can read the subcultural codes contained therein. Nonetheless, the t-shirts' subversive references, and the media discourses around the collections, issue a reminder that, like hip hop culture itself, these alternate representations will continue to circulate within the dominant logics of consumer culture. 
TranscUlturAl, vol. 6.1 (2014), 70-83.

http://ejournals.library.ualberta.ca/index.php/TC

\section{REFERENCES}

“About Us.” Conflict of Interest NYC. COI-NYC.com, 2012. Web. 20 Aug. 2014.

Adams, Brittany. "On Our Radar: Subversive Logo Tees from C.O.I. NYC." Style File blog. Style.com. Condé Nast Media, 19 Oct. 2012. Web. 20 Aug. 2014.

“Balenciaga.” Style.com. Condé Nast Media, 2014. Web. 20 Aug. 2014.

“Ballin Lyrics.” Genius. Genius Media Group Inc., 2014. Web. 20 Aug. 2014.

Briggs, Adam, and Paul Cobley. "II Like My Shit Sagged': Fashion, 'Black Musics' and Subcultures." Journal of Youth Studies 2.3 (1999): 337-52. Sociological Abstracts. Web. 20 Aug. 2014.

Chernikoff, Leah. "The 'Secret Agents' Behind Cult T-shirt Line Conflict of Interest Reveal Their Latest Collection.” Fashionista. Breaking Media, Inc., 28 Jan. 2013. Web. 20 Aug. 2014.

Conflict of Interest NYC. Tumblr.com, 2012. Web. 20 Aug. 2014.

Constine, Josh. "Rap Genius Raises \$40M, Changes Name to Genius, Launches Embeddable Annotations." TechCrunch. AOL Inc., 11 Jul. 2014. Web. 20 Aug. 2014.

Debord, Guy. Society of the Spectacle. 1967. Marxists.org, 2012. Web. 20 Aug. 2014.

Dery, Mark. "The Merry Pranksters and the art of the hoax." New York Times 23 Dec. 1990. Web. 20 Aug. 2014.

Dimitriadis, Greg. Performing Identity/Performing Culture: Hip Hop as Text, Pedagogy, and Lived Practice. 2nd ed. New York: P. Lang, 2009. Print.

Elliott, Hannah. "Hedi Slimane Should Flaunt Colette's Saint Laurent Parody Shirt, Not Ban It.” Forbes. Forbes.com, LLC, 4 Oct. 2013. Web. 20 Aug. 2014.

Epstein, Emily Anne. "Conflict of Interest: Counterfeit Couture or Tee Shirt Try-Hards?” New York Observer. Observer Media, 7 Sept. 2013. Web. 20 Aug. 2014.

“Explore Balenciaga Paris.” Balenciagafragrance.com. Balenciaga, 2014. Web. 20 Aug. 2014.

Gates, Jr., Henry Louis. The Signifying Monkey: A Theory of Afro-American Literary Criticism. New York: Oxford UP, 1988. Print. 
TranscUlturAl, vol. 6.1 (2014), 70-83.

http://ejournals.library.ualberta.ca/index.php/TC

Hall, Stuart. "The Work of Representation.” Representation: Cultural Representations and Signifying Practices. Ed. Stuart Hall. London: SAGE, 1997. 13-69. Print.

Hebdige, Dick. Subculture: the Meaning of Style. London: Methuen, 1979. Print.

Heffernan, Virginia. "Street Smart: Urban Dictionary.” New York Times 1 Jul. 2009. Web. 20 Aug. 2014.

Howe, Jeff. Crowdsourcing: Why the Power of the Crowd is Driving the Future of Business. New York: Three Rivers P, 2008. Print.

Hutcheon, Linda. A Theory of Parody: The Teachings of Twentieth-Century Art Forms. 1985. Champaign, IL: U of Illinois P, 2000. Print.

Jaworski, Adam, and Crispin Thurlow. "Introducing Semiotic Landscapes." Introduction. Semiotic Landscapes: Language, Image, Space. Ed. Adam Jaworski and Crispin Thurlow. London and New York: Continuum, 2010.1-40. Print.

Klein, Naomi. No Logo: Taking Aim at the Brand Bullies. Toronto: Knopf, 2000. Print.

Lievrouw, Leah A. Alternative and Activist New Media. Cambridge: Polity P, 2011. Print.

Lury, Celia. Brands: The Logos of the Global Economy. London and New York: Routledge, 2004. Print.

"Malcolm X Boulevard: Virtual Tour of Living Landmarks and Lenox Shadows." New York City Department of City Planning. NYC Department of City Planning, 2012. Web. 20 Aug. 2012.

Mukherjee, Roopali. “The Ghetto Fabulous Aesthetic in Contemporary Black Culture." Cultural Studies 20.6 (2006): 599-629. Communication \& Mass Media Complete. Web. 20 Aug. 2014.

“Niggas in Paris Lyrics.” Genius. Genius Media Group Inc., 2014. Web. 20 Aug. 2014.

Okonkwo, Uché. Luxury Fashion Branding: Trends, Tactics, Techniques. Basingstoke: Palgrave Macmillan, 2007. Print.

"Opinion: Mugging the Streets, Branding Fashion." Dazed Digital. Conflict of Interest NYC Tumblr, 2014. Web. 20 Aug. 2014.

Penney, Joseph. "From the Ghetto to the Shopping Mall: Taste, Signification, and Social Difference in the Contemporary Graphic T-Shirt." Conference Papers - National Communication Association, 2008. Communication \& Mass Media Complete. Web. 20 Aug. 2014. 
TranscUlturAl, vol. 6.1 (2014), 70-83.

http://ejournals.library.ualberta.ca/index.php/TC

Remsen, Nick. “The Next Big Thing: LPD New York and Conflict of Interest NYC, Spring '14.” Style File blog. Style.com. Condé Nast Media, 9 Sept. 2013. Web. 20 Aug. 2014.

Romero, Elena. Free Stylin': How Hip Hop Changed the Fashion Industry. Santa Barbara, CA: Praeger, 2012. Print.

Rose, Tricia. Black Noise: Rap Music and Black Culture in Contemporary America. Hanover, NH: UP of New England, 1994. Print.

---. “A Style Nobody Can Deal With: Politics, Style and the Postindustrial City in Hip Hop.” Microphone Fiends: Youth Music \& Youth Culture. Ed. Andrew Ross and Tricia Rose. New York: Routledge, 1994. 71-88. Print.

Small, Rachel. "Conflict of Interest NYC \& LPD New York Find Their Highs and Lows." Interview Magazine 9 Sept. 2013. Web. 20 Aug. 2014.

Stein, Marc. “Nets fined \$50,000 for Jay-Z's visit." ESPN New York. ESPN Internet Ventures, 8 April 2011. Web. 20 Aug. 2014.

Thomas, Dana. Deluxe: How Luxury Lost Its Luster. New York: Penguin, 2007. Print.

Troy, Nancy J. Couture Culture: A Study in Modern Art and Fashion. Cambridge, MA: MIT P, 2003. Print.

Urban Dictionary. UrbanDictionary.com, n.d. Web. 20 Aug. 2014. 